\title{
Long Term Results of Dacryocystorhinostomy in Adults
}

\author{
Sung-Won Chung, Young-Jun Chung, In-Sang Kim and Ji-Hun Mo \\ Department of Otorhinolaryngology-Head and Neck Surgery, College of Medicine, Dankook University, Cheonan, Korea
}

누낭비강문합술의 장기 추적 결과

정성원 · 정영준 · 김인상 · 모지훈

단국대학교 의과대학 이비인후과학교실

Received January 24, 2011

Revised March 23, 2011

Accepted March 24, 2011

Address for correspondence

Ji-Hun Mo, MD

Department of Otorhinolaryngology-

Head and Neck Surgery,

College of Medicine,

Dankook University,

359 Manghyang-ro, Dongnam-gu,

Cheonan 330-715, Korea

Tel +82-41-550-3974

Fax $+82-41-556-1090$

E-mail jihunmo@gmail.com
Background and Objectives The purpose of this study was to evaluate the long-term outcome of primary endoscopic dacryocystorhinostomy (DCR) or conjunctivo-dacryocystorhinostomy (CDCR) in adults with nasolacrimal duct obstruction.

Subjects and Method We retrospectively reviewed 31 eyes of 27 patients who underwent primary DCR or CDCR for anatomical or functional blockage of the lacrimal drainage system (4 males, 27 females, mean age $54.4 \pm 12.7$ years). The mean follow-up period was $45.4 \pm 10.8$ months. The main outcome measure for success was assessed by symptomatic improvement. Pre-operative CT findings and endoscopic findings, sites of obstruction, types of surgery, post-operative complications were evaluated and the outcome was assessed according to the level of obstruction and types of surgery.

Results Two years after the surgery, the success rate was $83.9 \%$ including complete resolution of symptoms $(64.5 \%)$ and partial improvement (19.4\%). No improvement was reported in $16.1 \%$. There was no significant difference in success rates of DCR according to the obstruction sites. Patients with functional blockage had worse success rate than those with anatomical obstruction.

Conclusion Both endoscopic DCR and CDCR had successful outcome in the long term control of epiphora and functional nasolacrimal duct obstruction showed worse prognosis when compared with anatomical obstruction.

Korean J Otorhinolaryngol-Head Neck Surg 2011;54:334-8

Key Words Dacryocystorhinostomy $\cdot$ Epiphora.
서 론

비내 접근법을 통한 누낭비강문합술은 West가 처음으로 기술하였으나 시야확보가 어렵고 누낭으로의 접근이 제한되 어 널리 보급되지는 못하였다. ${ }^{1)}$ 이후 비내시경의 도입 및 술 기의 발달로 수술 성공률이 향상되었고, 피부절개를 통한 외 부접근법에 비해 피부반흔이 없으면서 상처 회복이 빠르다는 장점 등으로 인해 보편화되었다. 외부 접근법에 의한 결막누 낭비강문합술은 상, 하 및 총누소관의 폐쇄가 있거나 내시경 누낭비강문합술이 실패한 경우 유용한 치료법으로 이용되어 왔으나, 수술 후 피부반흔 및 수술 중 주위 조직의 손상이나
출혈 증가, 술 후 회복기간 연장 등의 단점들로 인해 최근에 는 이런 단점들을 줄이고자 내시경하 결막누낭비강문합술이 소개되었고 이에 대한 수술 성공률들이 외부 접근법과 비교 되어 보고되고 있다. ${ }^{23)}$

하지만, 현재까지 보고되고 있는 누낭비강문합술 및 결막 누낭비강문합술의 대부분 연구들이 비교적 단기간의 결과 보 고인 반면, 장기간에 걸친 수술 결과들을 보고한 연구는 많 지 않다. 해외의 연구를 살펴보면 72 개월 이상의 장기간 추적 관찰 결과를 보고한 연구들이 있는 반면 국내 연구의 추적관 찰 기간은 12 개월 전후로 비교적 짧은 편이다. ${ }^{4-6)}$ 또한 추적 관찰 기간에 따라 누낭비강문합술의 치료 성공률이 변할 수 
있는데, Connell 등 ${ }^{4}$ 은 술 후 15개월의 치료 성적이 $78.6 \%$ 인 것에 반해 7년 째 치료 성적은 $89.3 \%$ 로 향상되었다고 보 고하였고, Kwon 등그는 기능적 비루관폐쇄 환자에서 실리콘 관 삽입술의 치료 효과가 추적관찰이 길어짐에 따라 낮아졌 다고 보고하였다. 이에 저자들은 본원에서 내시경하 누낭비 강문합술 및 결막누낭비강문합술을 받은 환자들 중 장기간 추적관찰이 가능했던 환자들을 대상으로 수술 성공률을 분 석하고, 수술 성공률에 영향을 주는 인자를 알아보고자 하 였다.

\section{대상 및 방법}

\section{대 상}

2007년 1월부터 2008년 6월까지 본원에 눈물흘림을 주 소로 내원한 환자 중 누낭조영술 상 비루관폐쇄로 진단 후 누낭비강문합술을 시행받은 59 안 중 24 개월 이상 추적관찰 이 가능하였던 27 명 31 안을 대상으로 하였다. 모든 환자에 서 술 전 안과 진료를 시행하였으며 외래에서 비내시경을 통 해 비강내의 상태를 검사하였다. 악안면 외상의 과거력 및 종 양에 의한 누도 폐쇄, 심한 골기형 등이 있는 경우는 연구대 상에서 제외하였다. 모든 환자에서 수술 전 누낭조영술을 시 행하여 폐쇄 부위에 따라 총누소관, 누낭, 낭-관 연결부위, 누관 및 폐쇄가 없는 기능적 눈물흘림증(Functional acquired nasolacrimal duct obstruction) 총 5그룹으로 분류 하였다. 또한 수술방법에 따라 내시경 누낭비강문합술(Endoscopic dacryocystorhinostomy)과 결막누낭비강문합술 (Conjunctivo-dacryocystorhinostomy)로 분류하였다.

치료 결과는 외래 방문 기록을 통해 수술 후 6 개월 및 24 개월 째 주관적 증상 호전 여부를 조사하였다. 술 후 눈물증 상이 완전히 없어진 경우 '완치(good)', 눈물증상이 있으나 수 술 전보다 줄어든 경우 ‘호전(partial)', 눈물증상이 지속되는 경우는 '실패(none)'로 나누어 평가하였고, 성공률은 완치와 호전을 합한 것으로 정의하였다. 최근까지 추적관찰이 이루 어지지 않은 환자들은 전화 설문을 통해 증상 호전 여부를 확인하였다.

\section{수술 방법}

수술은 두 명의 술자에 의해 전신 마취 하에서 시행되었고, 수술 방법은 다음과 같았다. 비점막 수축을 위해 $4 \%$ 리도카 인(lidocaine)과 $1: 1,000$ 에피네프린 혼합액으로 적신 거 즈를 중비도와 누낭 부위의 상악선(maxillary line) 점막 에 패킹하였다. 10 분 후 거즈를 제거하고, $2 \%$ 리도카인과 1 : 100,000 에피네프린으로 혼합된 마취액을 이용하여 구상돌
기 주변 점막과 상악선 점막 부위에 침윤 마취를 시행하였다.

내시경 누낭비강문합술의 수술과정은 상악선 점막 부위에 절개를 가한 후, freer elevator를 이용하여 구상돌기의 비 강 외측벽 접합부까지 점막 피판을 거상하였다. 이 후 구상 돌기의 상부를 절제한 후 누낭이 위치한 골부위를 노출시키 고, 골겸자를 이용해 전방으로 상악골의 전두돌기를 제거하 고, 후방으로 누골을 제거한 후 누낭을 노출시켰다. 누도탐 침자를 누점으로 통하여 누소관을 지나 누낭의 내측 후하단 부까지 삽입하여 누낭의 절제 부위를 확인하였다. Slit knife 와 No. $12 \mathrm{knife}$ 를 이용하여 누낭을 절개한 후 전방기저 점 막피판(anterior-based mucosal flap)을 만들어 누낭의 비강 내공을 통해 눈물이 잘 배출될 수 있도록 만든 후 총 누소관이 비강 내공을 통해 관찰되는 것을 확인한 후, 누소 관을 통해 주입한 식염수가 비강내공을 통해 잘 배출되는지 다시 확인하였다. 추가적으로 누소관에 실리콘관을 삽입하 여 누낭 절개부를 통해 비강으로 통과시킨 후 결찰하여 비 강 내에 위치시켰다. 실리콘관은 4 6개월 간 유지시킨 뒤 외 래에서 제거하였다.

결막누낭비강문합술의 수술과정은 내시경하에서 누낭을 절개한 후 전방기저 점막피판을 이용해 누낭의 비강 내공을 만드는 과정까지는 내시경 누낭비강문합술의 수술과정과 동 일하다. 이후 비내시경을 비강 내에 위치시킨 후, $16 \mathrm{G}$ needle을 medial canthal angle에 있는 medial fornix를 통 해 삽입하여 미리 만들어 놓은 누낭의 비강내공 부위로 나오 게 한 다음, sharp morsquito forcep을 이용하여 $16 \mathrm{G}$ needle로 만든 medial fornix와 비강 내 연결통로를 확장시켰 다. 터널을 통하여 lacrimal probe를 비강내로 삽입하여 비 내시경을 통해 probe의 끝이 비강의 외벽과 비중격의 중간 에 위치하게 하여, 삽입할 존스관의 정확한 길이를 측정하였 다. 측정한 길이로 만든 존스관을 삽입하고, 내시경으로 비 강내에서의 존스관의 위치를 확인한 후 Vicryl No. 5 를 이 용하여 존스관을 고정하였다.

\section{통계적 분석}

통계분석은 SPSS 13.0 version을 이용하여 Chi-square test, t-test로 검증하였고, 유의수준 $p$-value는 0.05 이하 로 정하였다.

\section{결 과}

대상 환자 31 안 중 남자는 4 안, 여자는 27 안이었고, 평균 나이는 $54.4 \pm 12.7$ 세로 26 세부터 71 세까지 분포하였다. 술 후 평균 추적관찰기간은 45.4 개월이었다. 
누낭비강문합술 외 부가적으로 5 안에서 부비동내시경수 술을 시행하였으며, 1 안에서 비중격교정술을 시행하였다. 24 안에서 내시경적 누낭비강문합술을 시행하였으며, 결막누낭 비강문합술은 총누소관 폐쇄 환자의 7안에서 시행하였다. 대표적 술 전, 술 후 누낭조영술 소견과 내시경 소견은 Fig. 1 과 같다. 수술 방법에 따른 치료 성적은 누낭비강문합술이 $85.2 \%$, 결막누낭비강문합술이 $85.7 \%$ 의 성공률을 보여 통계 적으로 유의한 차이가 없었다. 30 안에서 누소관에 실리콘관 을 삽입하였으며, 1 안에서는 실리콘관을 삽입하지 않았다.

술 전 시행한 누낭조영술 27 안에서 누도 폐쇄 소견을 보였 으며, 4 안에서 누도 폐쇄가 없는 기능적 비루관폐쇄 소견을 보 였다. 누도의 폐쇄 환자는 각각 총누소관이 7안, 누낭 14안, 누낭-누관 접합부 4 안, 누관 2안이었다(Table 1).

해부학적 비루관폐쇄로 진단된 환자들에서 수술 후 6 개월 째 치료 성적은 총누소관의 $85.8 \%$ 에서 눈물증상이 호전되 었던 반면 $14.2 \%$ 에서는 전혀 호전이 없었다. 누낭과 누낭-누 관 접합부, 누관에서는 $100 \%$ 눈물증상이 모두 호전되었던 반면, 기능적 비루관폐쇄 환자는 $100 \%$ 전혀 호전이 없었다 (Table 2). 해부학적 비루관 폐쇄로 진단된 환자들에서 수술 후 2 년째 치료 성적은 총누소관 및 누낭-누관 접합부, 누관 에서는 $100 \%$ 눈물증상이 호전되었다. 누낭에서는 $92.8 \%$ 에 서 호전되었으며, $7.2 \%$ 에서 전혀 호전이 없었다. 수술 후 6 개월 및 2 년째 치료 성적은 해부학적 비루관폐쇄가 관찰된 4그룹 간에 통계적으로 유의한 차이를 보이지 않았다. 비루 관폐쇄가 확인된 4그룹과는 다르게 기능적 비루관폐쇄 환자 의 치료 성적은 $100 \%$ 에서 증상이 전혀 호전되지 않았으며,

Table 1. Pre-operative lacrimal drainage system abnormalities

\begin{tabular}{lc}
\multicolumn{1}{c}{ Sites of onbstruction } & No. $(\mathrm{n}=31)$ \\
\hline No obstruction & 4 \\
Common canaliculi & 7 \\
Lacrimal sac & 14 \\
Duct-sac junction & 4 \\
Lacrimal duct & 2 \\
\hline
\end{tabular}

이는 비루관폐쇄가 확인된 4 그룹의 치료 성적에 비해 유의 하게 낮았다 $(p<0.001)$ (Table 3).

\section{고 찰}

눈물흘림은 임상에서 흔히 볼 수 있는 증상으로 다양한 원인에 의해 발생되며 크게 눈물 분비와 눈물 배출 두 요소 의 상호관계에 의해 발생여부가 결정된다. 누도의 폐쇄와 같 은 구조적 이상이 있거나 눈물을 짜주는 기능적 이상이 있 는 경우 눈물의 배출이 저하되어 유루가 발생하게 된다. ${ }^{8}$ 누 도의 협착 및 폐쇄 등을 진단하기 위해 탐침법, 눈물소관 관 류법, 존스색소유출검사, 색소검사, 누낭조영술. 누도신티그 라피. 컴퓨터 단층촬영 등의 여러 방법들이 사용되고 있다.

누낭비강문합술은 비루관폐쇄로 인한 유루증을 치료하기 위해 누도의 폐쇄부위를 우회시키는 방법으로 1904년 Toti9) 에 의해 처음 시행되었다. 피부절개를 통한 비외접근법이 사 용되었으며 술기의 발달과 함께 현재 성공률이 90 95\%에 이르고 있다. 비강을 통한 누낭비강문합술은 1893년 Caldwell ${ }^{10)}$ 이 비루관의 비내관상거술(endonasal trephination)을 이용하여 처음으로 시도한 이래 내시경의 발달과 함 께 도입되었다. 내시경을 이용한 누낭비강문합술은 주변 조 직의 손상 및 출혈이 적고, 미용상의 장점과 술 후 이환율이 적다는 장점이 있으며, 최근에는 내시경의 발달과 함께 수술 시야가 확보되고 비강내 조작이 용이해지면서 성공률이 향 상되었다. ${ }^{11)}$

누도의 폐쇄 부위를 살펴보면 Choi 등 ${ }^{12)}$ 은 비루관, 총누 소관, 누낭의 순으로 보고하였고, Yung과 $\operatorname{Hardman}^{13)}$ 은 누 낭과 비루관의 폐쇄가 누소관의 폐쇄보다 2 배 가량 많다고 하였으며, Connell 등 $)^{4}$ 은 누소관의 폐쇄가 비루관의 폐쇄보 다 3 배 이상 많은 것으로 보고하였다. 본 연구에서는 앞 두 연구와 달리 총 31 예 중 누낭의 폐쇄 소견이 가장 많았다. 연 구마다 폐쇄 부위의 빈도가 다른 것은 누낭비강문합술에 관 한 연구의 대부분이 비교적 적은 환자를 대상으로 이루어졌
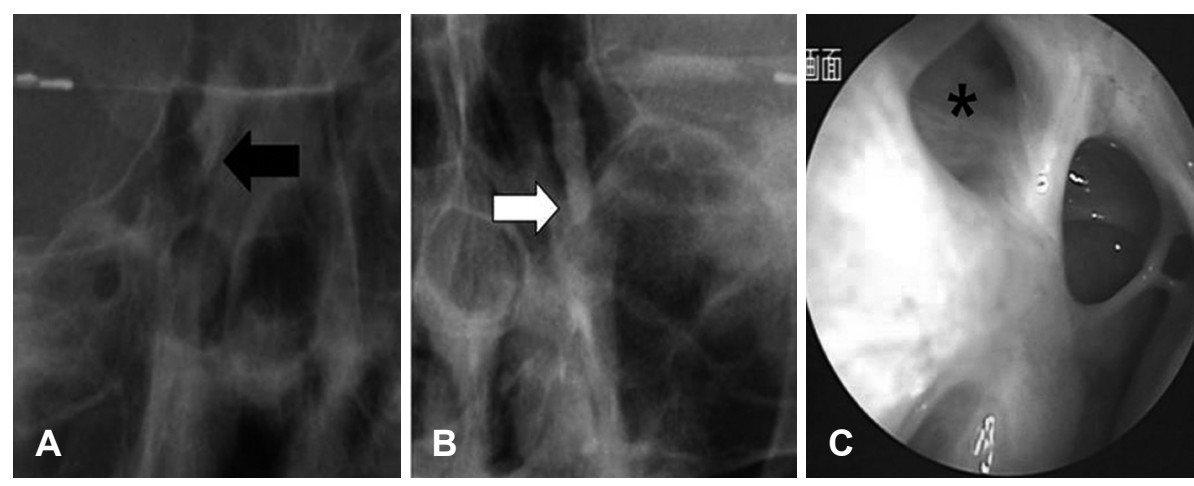

Fig. 1. Preoperative dacryocystographic findings and a post-operative endoscopic finding. A dacryocystogram shows complete occlusion at nasolacrimal duct-sac junction (black arrow)(A). A dacryocystogram shows dilated nasolacrimal duct and occlusion at nasolacrimal duct (white arrow)(B). The rhinostomy opening is wide and well patent $(*)$ and agger nasi cell is well opened (C). 
Table 2. Results of DCR in 31 eyes after 6 months

\begin{tabular}{|c|c|c|c|}
\hline \multirow{2}{*}{ Level of lacrimal obstruction ( $n=$ no of involved eyes) } & \multicolumn{3}{|c|}{ Symptomatic improvement at 6 months (no of cases and \%) } \\
\hline & Good & Partial & None \\
\hline Common canaliculi $(n=7)$ & $3(42.9 \%)$ & $3(42.9 \%)$ & $1(14.2 \%)$ \\
\hline Lacrimal sac $(n=14)$ & $7(50 \%)$ & $7(50 \%)$ & $0(0 \%)$ \\
\hline Duct-sac junction $(n=4)$ & $2(50 \%)$ & $2(50 \%)$ & $0(0 \%)$ \\
\hline Lacrimal duct $(n=2)$ & $0(0 \%)$ & $2(100 \%)$ & $0(0 \%)$ \\
\hline No obstruction $(n=4)$ & $0(0 \%)$ & $0(0 \%)$ & $4(100 \%)$ \\
\hline
\end{tabular}

DCR: dacryocystorhinostomy

Table 3. Results of DCR in 31 eyes after 24 months

\begin{tabular}{lccc}
\hline \multirow{2}{*}{ Level of lacrimal obstruction ( $\mathrm{n}=$ no of involved eyes) } & \multicolumn{2}{c}{ Symptomatic improvement at 24 months (no of cases and \%) } \\
\cline { 2 - 4 } & Good & Partial & None \\
\hline Common canaliculi $(n=7)$ & $6(85.7 \%)$ & $1(14.3 \%)$ & $1(7.2 \%)$ \\
Lacrimal sac $(n=14)$ & $10(71.4 \%)$ & $3(21.4 \%)$ & $0(0 \%)$ \\
Duct-sac junction $(n=4)$ & $3(75 \%)$ & $1(25 \%)$ & $0(0 \%)$ \\
Lacrimal duct $(n=2)$ & $2(100 \%)$ & $0(0 \%)$ & $4(100 \%)$ \\
No obstruction $(n=4)$ & $0(0 \%)$ & $0(0 \%)$ & 4 \\
\hline
\end{tabular}

DCR: dacryocystorhinostomy

기 때문으로 생각된다.

수술 성공률에 영향을 미치는 요인으로 술자의 술기가 가 장 중요하고, 유루의 지속시간이 길거나 외상의 과거력이 있 는 경우, 실리콘관을 삽입한 경우 성공률이 감소하는 것으로 보고되었다. ${ }^{14)}$ 또한 다른 연구에서는 연령, 성별, 폐쇄부위, 누낭의 크기 등은 성공률과 연관성을 찾을 수 없었다고 보 고되었다. ${ }^{4)}$ 본 연구에서는 외상의 과거력이 있는 환자 7 명 중 3 명에서 증상 호전이 전혀 없었으며 1명에서 일부 증상 호전 이 있는 것으로 나타나 평균 수술 성공률에 비해 낮은 성적 을 보였다. 수술 방법에 따른 치료 성적은 내시경 누낭비강문 합술을 시행한 그룹이 $83.8 \%$ 였고, 결막누낭비강문합술을 시 행한 그룹이 $88.9 \%$ 로 두 그룹 사이에 유의한 차이는 없었다. 본 연구에서 시행한 누낭비강문합술의 경우 대부분 실리콘 관을 삽입하여 삽입 여부에 따른 치료 성적을 비교할 수는 없었으나, 비교적 높은 성공률을 보였다. 그러나 최근 실리 콘관 삽입 여부에 따른 치료 성적에 유의한 차이가 없다는 연구보고에 따라 점차 실리콘관을 삽입하지 않는 술식이 보 편화되고 있는 추세이며 현재 본원에서도 누낭비강문합술에 서 실리콘관을 삽입하지 않고 있다. ${ }^{15)}$ 폐쇄 부위에 따른 치 료 성적을 보면 Choi 등 ${ }^{12}$ 은 누낭-누관 접합부의 치료 성적 이 $100 \%$ 로 가장 좋았던 반면 누낭의 치료 성적이 $69.2 \%$ 로 가장 낮았다. Yung과 $\operatorname{Hardman}^{13)}$ 은 술 후 6개월 째 누낭 및 누관의 치료 성적이 $93 \%$, 총누소관의 치료 성적이 $88 \%$ 로 폐쇄 부위에 따른 치료 성적에 유의한 차이가 없었으나 누 소관 폐쇄 환자에서 증상이 모두 호전된 비율이 다른 부위 에 비해 다소 낮았다고 보고하였다. 본 연구에서는 술 후 2 년 째 총누소관, 누낭-누관 접합부, 비루관이 막혔을 때의
치료 성적은 $100 \%$ 였으며, 누낭의 치료 성적은 $93.8 \%$ 로 다소 낮았으나 통계적으로 유의한 차이는 없었다. 그러나 결막누 낭비강문합술을 시행한 총누소관의 치료 성적이 2 년 째에 다소 좋아진 경향이 있었으며, 이는 시간이 지나면서 총누소 관이나 누낭의 개구부에 있던 점막의 부종 및 육아조직 등 이 소실되어 치료 성적에 영향을 주었을 것으로 생각된다. 술 자의 숙련도 및 수술 방법, 대상 환자의 누도 폐쇄 정도에 따 라 치료 성적이 달라질 수 있을 것이다.

한 가지 흥미로운 점은 누낭조영술에서 누도의 폐쇄 소견 없이 눈물흘림 증상을 호소하는 기능적 비루관폐쇄 환자의 6 개월 및 2 년 째 치료 성적이 $0 \%$ 로 매우 저조한 것으로 나타 났다. 본 연구와 달리 Cheung 등히은 원발성 비루관폐쇄 환 자와 기능적 비루관 폐쇄 환자 모두에서 누낭비강문합술을 통해 술 후 2 개월 째 성공적인 치료 성적을 얻었다고 보고하 였다. Jeong 등기는 기능적 비루관폐쇄 환자에서 탐침법을 통해 저항부위와 정도에 따라 분류하여 실리콘관 삽입술 후 6 개월 째 치료 성적을 비교하였으나 술 후 군간의 만족도 차 이는 없었으며 평균 $95.2 \%$ 의 높은 치료 성적을 보고하였다. Angrist와 Dortzbach $^{18)}$ 는 기능적 비루관폐쇄 환자를 탐침 법시 느껴지는 저항의 정도에 따라 분류하고 치료 성적을 비 교하였다. 연구 결과 경도 및 중등도 저항이 있는 19 안 중 18 안에서 증상이 호전되었으나 심한 저항이 있는 4 안 중 3 안에 서 증상이 호전되지 않아 가장 중요한 예후 인자는 비루관 폐쇄의 정도라고 보고하였다. 본 연구의 기능적 비루관폐쇄 환자의 경우 탐침법을 시행한 기록이 없어 저항의 정도는 확 인할 수 없었다.

비루관폐쇄 환자에서 누낭비강문합술에 대해 그 동안 국 
내에서 많은 보고가 있었으나 장기간에 걸친 수술결과에 대 한 보고는 많지 않았다. Choi 등 ${ }^{12)}$ 이 보고한 누도 폐쇄 부위 에 따른 누낭비강문합술의 치료 성공률에 관한 연구에서 추 적관찰기간은 평균 5.2 개월이었으며, Lee와 $\mathrm{Jin}^{11)}$ 이 보고한 후누낭접근술에 관한 연구에서 역시 추적관찰기간은 8 18 개월로 Connell 등희의 해외 연구 추적관찰기간 78개월보다 비교적 짧았다. 비교적 장기간에 걸친 본 연구의 결과는 비 루관폐쇄 환자에서 내시경적 누낭비강문합술 및 결막누낭비 강문합술을 통해 $83.9 \%$ 의 성공적인 치료 성적을 얻었으며, 술 후 2 년째 치료 성적에서 6 개월째 치료 성적에 비해 증상 이 호전된 환자의 비율이 더 높아 향상된 치료 성적을 보였 다. 또한 누낭조영술에서 폐쇄 소견이 있는 환자에 비해 폐 쇄 소견이 없는 기능적 비루관폐쇄 환자에서 더 낮은 치료 성공률을 보이므로 수술대상환자의 선정 시 이 같은 점을 고 려하여야 할 것으로 생각된다.

\section{REFERENCES}

1) West JM. A window resection of the nasal duct in cases of stenosis. Trans Am Ophthalmol Soc 1910;12(Pt 2):654-8.

2) Park MS, Chi MJ, Baek SH. Clinical study of endoscopic endonasal conjunctivodacryocystorhinostomy with Jones tube placement. Ophthalmologica 2007;221(1):36-40.

3) Trotter WL, Meyer DR. Endoscopic conjunctivodacryocystorhinostomy with Jones tube placement. Ophthalmology 2000;107(6):1206-9.

4) Connell PP, Fulcher TP, Chacko E, O’ Connor MJ, Moriarty P. Long term follow up of nasolacrimal intubation in adults. Br J Ophthalmol 2006;90(4):435-6.

5) Lee DP, Yang SW, Choi WC. The relation between nasal cavity size and success rate in endonasal dacryocystorhinostomy. J Korean Ophthalmol Soc 2000;41(5):1118-23.
6) Huh D, Son MG, Kim YD. Silicone intubation for fuctional nasolacrimal duct obstruction. J Korean Ophthalmol Soc 2000;41(11):2303-7.

7) Kwon YH, Lee YJ. Long-term results of slilcone tube intubation in incomplete nasolacrimal duct obstruction (NLDO). J Korean Ophthalmol Soc 2008;49(2):190-4.

8) Jones LT. An anatomical approach to problems of the eyelids and lacrimal apparatus. Arch Ophthalmol 1961;66:111-24.

9) Toti A. Nuovo metodo conservatore dicura radical delle sopourazioni croniche del sacco lacrimale (dacriocistorhinostomia). Clin Mod Firenze 1904;10:385-7.

10) Caldwell GW. Two new operations for obstructions of the nasal duct with preservation of the canaliculi. Am J Ophthalmol 1893;10:189.

11) Lee KC, Jin SM. Analysis of recurrence after endoscopic dacryocystorhinostomy. Korean J Otolaryngol-Head Neck Surg 2003;46(6): 488-90.

12) Choi JC, Jin HR, Moon YE, Kim MS, Oh JK, Kin HA, et al. The surgical outcome of endoscopic dacryocystorhinostomy according to the obstruction levels of lacrimal drainage system. Clin Exp Otorhinolaryngol 2009;2(3);141-4.

13) Yung MW, Hardman-Lea S. Analysis of the results of surgical endoscopic dacryocystorhinostomy: effect if the level of obstruction. $\mathrm{Br}$ J Ophthalmol 2002;86(7):792-4.

14) Mannor GE, Millman AL. The prognosis value of preoperative dacryocystorhinostomy. Am J Ophthalmol 1914;12:659.

15) Unlu HH, Gunhan K, Baser EF, Songu M. Long-term results in endoscopic dacryocystorhinostomy: is intubation really required? Otolaryngol Head Neck Surg 2009;140(4):589-95.

16) Cheung LM, Francis IC, Stapleton F, Wilcsek G. Symptom assessment in patients with functional and primary acquired nasolacrimal duct obstruction before and after successful dacryocystorhinostomy surgery: a prospective study. Br J Ophthalmol 2007;91(12):1671-4.

17) Jeong HW, Cho NC, Ahn M. Results of silicone tube intubation in patients with epiphora who showing normal finding in dacryocystography. J Korean Ophthalmol Soc 2008;49(5):706-12.

18) Angrist RC, Dortzbach RK. Silicone intubation for partial and total nasolacrimal duct obstruction in adults. Ophthal Plast Reconstr Surg 1985;1(1):51-4. 